\title{
Corporate Culture as an Effort of Company Transformation
}

\author{
Doli M. Ja'far Dalimunthe \\ Department of Management \\ Universitas Sumatera Utara \\ Medan, Indonesia \\ sidolidalimunthe@gmail.com
}

\author{
Sabrina Cyndi Azhari Pasaribu \\ Department of Management \\ Universitas Sumatera Utara \\ Medan, Indonesia \\ sabrinacyndiazharipasaribu@yahoo.com
}

\begin{abstract}
Applying corporate culture has become a demand that can not be negotiable by the company to still exist in the increasingly fierce competition today. Not only for big companies, corporate culture is now also considered very important to be applied by small companies though. Companies that are only profit-oriented can be sure to falter at any time. This is reflected in CV Savanro Jaya Ananda company engaged in the distribution of goods. This company stands due to the turnover of distributors in the region so that the entire system even employees also including the move from the previous company. In the absence of the vision, mission and values that bind its employees, the company runs ineffectively, inefficiently and even loses hundreds of millions of rupiah due to the lack of supervision and the low value and morale of its employees. As a result, in mid-2017, the company terminated its working relationship with PT Unilever Indonesia Tbk. The method used in this research is descriptive qualitative method with in-depth interview to explain the indicators forming corporate culture, namely vision, mission and value. The population in this study amounted to 22 employees. The sample in this study using Convenience Sampling consisting of 10 employees. Results of this research are to investigate and prepare a corporate culture as what is appropriate to be applied in CV Savanro Jaya Ananda in an attempt to transform this company into a strong company and ready to compete, although it's still a small scale company.
\end{abstract}

Keywords - corporate culture, company transformation, distributor

\section{INTRODUCTION}

Distribution is an economic activity that connects between production and consumption activities. According to [1], distribution is a process of marketing activities that aims to facilitate the activities of distributing goods or services from the producers to the consumer. The executor of this activity is called a distributor. Distributors are now a choice of profession in the community because it is considered promising as the population increases, the increasing needs of life and economic conditions that have been getting better. This opportunity is utilized by CV Savanro Jaya Ananda (CV SAJADA) and in November 2014 the company officially became the distributor of Unilever products in Tapanuli Tengah region which is a transition from previous distributor Unilever, PT Putra Nusantara (PNS).
CV SAJADA has 22 employees divided into four parts of activities. First is the marketing-salesman consisting 6 employees. The second is the administrative section consisting of 2 employees. The third is the warehouse section of 5 employees consisting of 1 head warehouse, 1 warehouse admin and 3 helpers. And fourth is the delivery section consisting of 2 employees. All of these employees work together to distribute products $>500$ items to supermarkets, minimarkets, grocers to small shops in the market with a total of 710 stores.

In reality, employees exhibit unproductive attitudes and performance. Starting from the monthly evaluation of employee absenteeism, there are still many employees who are late in the morning and rest more than the specified hours. The owner has set sanctions and also entrusted a supervisor, but still there is no significant change in the employee. When researchers join the warehouse section, goods in the warehouse look messy and not by the arrangement of postal products. After the goods are collected and separated on a perinvoice basis, the item will be checked by the warehouse head and then put into the delivery car.

The company has 2 shipping cars. However, during the observation, this section is still not effective and efficient in carrying out the route of the goods. Plus not routine checks the feasibility of vehicles cause the vehicle is often problematic and lead to pending orders. When researchers participated in the process of delivering goods to the store, almost all of the shops visited complained of items that did not come, the salesmen who do not regularly visit the store until there is a store order item rigged by the sending team.

The salesman team routinely conducts a morning briefing led by the supervisor to discuss store visits yesterday and the day. The owners also often join during the morning briefing to direct and discuss the smooth distribution. However, the owner often finds some salesmen who do not even plan the route of visits and targets that must be achieved per day. Also the owners also often get reports that after the briefing, some salesmen do not directly visit the store.

Continue to the sales administration section. Orders from salesmen should be printed directly. However, at the time of 
observation, administrative staff still delayed printing orders from salesmen

These things continue to happen even though the owners have issued Warning Letter 1, 2 and 3 and even have laid off some employees who crossed the line. The company has also recruited several new employees, but still the competence of human resources in this area is still low. Firing all the old employees to renew the company is judged by the owner not as an appropriate step, because in addition to consuming a lot of time, effort and cost, there is no guarantee that newly recruited employees will be better performing.

The flow of goods from principals is not in line with the needs of the people in this area. Distributors are required to accept shipment specified by Unilever. This is considered less profitable because it means that distributors must accommodate goods that are not necessarily needed market. Plus the delivery schedule of goods by the principal was not regular.

Until the end of 2016, the company began to experience greater losses. Starting from the unfolding case of embezzlement of money payment shop worth tens of millions of rupiahs by salesmen. Error reporting tax value by administrative employees resulted in the company losing millions of rupiahs. The unclear role of supervisors in supervising and directing subordinates to create opportunities to misuse money, working hours and theft of goods by employees.

In February 2017, researchers participated in a shop visit with a salesman and observed that the entire store complained that the goods had not been delivered because the promised goods were not in the warehouse. In addition, the store also recognizes that the price of Unilever products they buy from traders is lower and more complete than the official distributor itself. Until May 2017, CV SAJADA decided to terminate the working relationship with the principal, PT Unilever Indonesia.

Based on the owner's point of view and also the observation of the researcher, it is considered that the cause of the company's lid can be divided into three aspects. The first aspect is the absence of a company vision. According [2], vision is a series of sentences that express the ideals or dreams of an organization or company to be achieved in the future. In [3], vision is the ability to look; ability to understand what will be realized in the future; ideas that exist in the dream of something. CV SAJADA has no specific goals or extraordinary things to be achieved together in the future. The company is still driven by sales targets alone, profit-oriented.

The second aspect is the neglect of the company's mission. The mission is a strategic action to achieve organizational vision [4]. In [5], it is stated that mission is a special task that is the responsibility of a person or group of people - specific task a person or group is charged. Because the company does not have a vision and still only driven by sales targets alone, then the mission that has been run by CV SAJADA is all efforts to achieve sales targets, such as promoting promotions and giving sales bonuses to employees.
The third aspect is the negligence of corporate value. According to [6], value is contained in the human conscience that gives more basic and moral principles which is the standard of beauty and efficiency or wholeness of conscience. According to [7], values are "basic assumptions about what ideals are desirable or worth striving for."

Seen from the above explanation that the thing that plays an important part in this case is the low value owned by its employees. Lack of disciplined work attitude, a sense of responsibility in completing the work, the tendency to steal goods and the low level of honesty of employees in this company. There is still a lack of awareness of employees to instill values that are even very common in the eyes of the public

Based on the whole phenomenon, then this company needs to make improvements by transforming the company. Organizational transformation is the process of strategic change from input to competitive output through an internal process. [8] argue that to adapt to market changes the company must create competence by transforming the organizational structure associated with operational transformation, corporate self-renewal transformation, and strategic transformation. The transformation of the company emphasized in this study is the transformation of self-renewal through the application of organizational culture.

According to [9], organizational culture is a shared perception shared by members of the organization. [10] defines culture as: "a pattern of shared basic assumptions that the group learns as it has worked out adequately and, therefore, to be taught to new members as the correct way you perceive, think, and feel in relation to the problems. According to [11] culture is: "The set of important assumption (often unstated) that members of community share in common".

From the expert opinion above, the corporate culture indicator consists of three aspects of namely, vision, mission and value. In the formation of organizational culture, it takes deep understanding of the future sustainability of the company from all elements that exist, ranging from owners to employees. Therefore, the researcher will find out the experience of the company's employees and analyze the phenomenon from the employee's point of view in this company. It is intended to view and evaluate the company thoroughly, both from the eyes of the owner and also the employee to prepare what kind of corporate culture is appropriate to be applied in CV SAJADA as an effort to transform this company.

\section{RESEARCH METHODS}

This research uses qualitative descriptive research method in the form of case study. Methods of data collection is done by way of in-depth interview to explain the corporate culture indicators, namely vision, mission and value. The population in this study amounted to 22 employees. The sample in this study using Convenience Sampling consisting of 10 employees. Interview technique is a structured interview, where researchers have prepared points of questions that will be asked of the respondents. The research question amounted to 37 items divided into three parts. The first section consists 
of 22 questions that discuss the experience of respondents during work in the company. The second part consists of 9 questions that discuss the knowledge of respondents about organizational culture indicators, namely vision, mission and values. The third section consists of 6 questions that discuss the respondent's perception of what organizational culture indicators are appropriate to be applied to this company in the future.

In addition, the researchers also collected data by interviewing the owner, documentation of company reports and conducting pre-research observations in the work environment CV SAJADA covering office and corporate warehouse located at Jl. Pesantren Komplek Elok Permai, Pandan, Tapanuli Tengah.

\section{RESEARCH RESULT}

\section{A. Respondents' Experience}

During the work at CV SAJADA, respondents assessed there are some working systems that need to be improved. Respondent senses the lack of supervision from the supervisor or the owner of the employee's performance. Too many employees are employed and it is not worth the sales figures achieved. Also, employees owned do not have the quality and good capability of doing the work. There are also respondents who emphasize the firmness and immediacy in the provision of rewards and punishment, especially giving sanctions to employees with problems. Respondents also stated that the stock of goods in the warehouse should be managed well, both regarding availability and regarding accuracy of the amount. Other respondents acknowledged that the work system at the company was good and felt there was nothing to be improved.

Respondents acknowledge there are some work systems that they like when working at CV SAJADA. Respondents feel that they are given guidance to know how a job can be safely and controlled. There are also respondents who are happy with the allowed to listen to music during working hours, because this can increase the productivity of respondents while working and improve the mood in case of disputes with colleagues. Respondents were pleased with the existence of clear working hour regulations. Respondents also stated that the salary given by this company is greater and the employee's welfare is also highly regarded. Almost all respondents emphasize one thing, the work environment in this company nuanced kinship. Other respondents said there was nothing that he enjoyed during his work here.

Some of the advantages of the company disclosed by respondents include a comfortable working environment, strong sense of kinship between employees and the owner and the owner's tolerance of mistakes made by employees, not immediately fired. While the shortcomings of the company, among others, less assertive sanctions given to employees who make mistakes, so that employees do not feel the deterrent effect and often repeat the mistake. Respondents also stated that the role of supervisors does not appear to be mandated to oversee the company's operations. There are also respondents who expressed too many workdays. Plus the company is less selective in recruiting human resources so that HR recruited is not competent in carrying out its duties. Other respondents said there was no shortage of this company.

The next question is about the ability and cohesiveness of his colleagues. Respondents assessed that many employees avoided their responsibilities. There are still employees who justify themselves and blame others when there is a job dispute. And it turns out some respondents stated that there are colleagues who "apple polisher". Several other respondents stated that the employees of CV SAJADA were compact and some were able to complete the task by the direction.

Asked about job satisfaction, some employees expressed satisfaction with the results of their work so far, while others expressed not satisfied with the results of his work because he was not careful in doing his job, has not been able to contribute useful knowledge for the company and feel has not enlivened the maximum effort to make the company this became a respected company like other distributor companies.

The biggest motivation of the respondents to work every day is family. Respondents strongly emphasize that they work to support their families and parents. The compensation offered by the company is quite interesting. There are also respondents who add that they are enthusiastic to work because they feel comfortable working in this company. The strong relationship of kinship and also the desire to develop themselves also become the motivation of respondents to work. Other respondents stated that their motivation was to work not to become unemployed.

Conversely, the things that make lazy respondents work, among others, the stock of goods in the warehouse is increasingly incomplete so that the impact on bonuses that are eliminated. Unsupporting weather and accumulated employment reports also left respondents lazy to work. In addition, co-workers who are difficult to work with to complete the work also greatly affect the majority of respondents. Other respondents said no one made him lazy to work.

Speaking of targets, all respondents stated that they did the job on target and the results were sometimes achieved and sometimes not. In the achievement of targets, the majority of respondents said they prefer to do so in accordance with the direction of leadership rather than in their way, because respondents believe that the direction must be for the good of the company. Some respondents added that sometimes they also improvised in their way when needed. Other respondents said they preferred their way because sometimes the boss's procedures were not so clear.

All respondents stated that they had made a mistake. The majority of mistakes made by respondents are often late to come to the office. In addition, respondents also admitted to mistakes that harmed the company such as misreporting taxes, lack of accuracy of employees in collecting and delivering goods to order and miscellaneous goods in the warehouse when the respondent occupying the position as head of the warehouse.

When asked what respondents expect when working in a company, the majority of respondents' answers are career development, knowledge and self-experience. Then followed 
by the hope of getting a decent compensation and other respondents expressed hope to enter a family working environment. In line with the question of what companies do to make employees loyal, the majority of respondents want companies to pay more attention to their employees, both socially and in their well-being, compensation and work-life balance. Then the respondents also added the need for a clear career path, openness between leaders and employees as well as a compact and kinship work environment.

Respondents are then asked to name the values or principles of life they apply every day, professional, indiscriminate, helpful, disciplined, honest, responsible, unapple polisher, unyielding, diligent, work with heart and respect each other.

Regarding the owner's leadership, the majority of respondents considered that the owner was still less assertive in the supervision and enforcement of regulations to the troubled employee. Respondents stated that the owner was less focused in this business because it shared his thoughts with other businesses. Then the owner is considered not open with input or opinion from his subordinates. Some respondents stated that his leadership had been good, wise in making decisions and regulations could make his employees become better figures.

Some respondents considered that the employee achievement in this company has not been maximally appreciated by the owner. While others stated that the achievement of employees here has been well appreciated, as evidenced by an increase in position if the employee shows a satisfactory performance. Owners also regularly conduct meetings to discuss the achievement of salesman targets, so that respondents feel directed to achieve it. There are also respondents who stated that there is no assessment of performance in this company.

The majority of respondents acknowledge that the owner is very concerned about his employees, as evidenced by the presence, participation and assistance of the owner when employees experience misfortune or there is an event held by employees. But there are respondents who stated that the owner is only concerned with the turnover only.

Regarding the employer's attitude toward the mistakes made by employees, some respondents stated that the owner is less assertive in giving punishment to employees who are very problematic. Some respondents also stated that the owners did not solve the problems in the office, but were immediately sentenced to the place, the respondents judged that they could not provide explanations, pleadings or opportunities to discuss the problem. While some other respondents judge that the attitude of the owner is right.

The majority of respondents stated that leaders who can increase productivity is an open figure, able to respect each other, share and exchange ideas. Respondents also added that the figure is concerned with the lives and welfare of its employees and also has the capability of being a leader, that is firm, able to make wise decisions and fast, honest, responsible and full of brilliant ideas.
Speaking of colleagues, all respondents stated that coworkers who can create a spirit of work are professional colleagues and responsible for completing the work. Respondents also emphasize co-workers who are familial, help each other and can work together on teams. Respondents also added that colleagues are not the ones who like to face to the boss and blame others.

There are various factors that respondents assessed as the cause of the collapse of this company. Starting from the lack of supervisory supervision and assertiveness of owners in giving sanctions. Next is the low quality of human resources employed in this company. Respondents judged that the low value of employee honesty so much stolen goods and embezzled sales money, the low discipline and mindset of employees about the job so that there is no sense of ownership and not thinking about long-term effects for himself and the company. And furthermore from the external factors, where respondents judge that the difference of interests of distributors and principals, the selling price of goods is much more high than the price of traders and often empty of goods that cause customer confidence in the company declined.

Respondents were then asked to explain what can be done to prevent the company's pullback. The majority of respondents said that the supervision is tightened, the sanctions given more assertive and hastened. Then the respondents added that the troubled employee was immediately removed and recruited new, more competent employees. Establish and embrace employees so that employees are willing to work together and have a sense of "owning a company" so that he can work wholeheartedly and exert his unlimited capabilities without having to be told. Respondents also added that the principal relationships and distributors could be straightened out.

A lot of hope that the respondents said to revive this company later. The majority of respondents stated that the recruited human resources are people who are truly qualified and competent in carrying out their responsibilities. In addition, respondents also stressed the importance of employing employees who uphold values, so events such as dishonesty, theft, embezzlement, laziness, and indiscipline can be avoided. Respondents also added that in the future the company could improve the organizational structure and adjust the number of employees in accordance with the need for operational costs not to swell so that the quality of compensation can be more pronounced for its employees.

\section{B. Knowledge of Respondents on Organizational Culture Indicators}

The majority of respondents interpret the vision as a goal and hope. Other respondents said they did not know the meaning of the vision. When asked about the company's vision, the majority of respondents said the company already has a vision. The form of corporate vision they express is like promoting a company and a high turnover. Other respondents stated that the company did not have a vision and one respondent said they did not know. The majority of respondents said that they have their own vision during the work is to advance the company because it will automatically 
be in line with the increase in the welfare of its employees. Another respondent stated his vision was to support his family. There are also respondents who said not know.

Respondents interpret the mission in various ways. Some interpret the mission is the way, direction, purpose, plan, longterm goals and some are not known. The majority of respondents stated that the company already has a mission, namely from the operational rules set by the company. Other respondents said the company did not yet have a mission because there was no vision. One respondent said he did not know. Regarding its own mission during the work, some respondents do so by seeking good performance, such as discipline in working hours, completing the report on time and reaching the set targets. Other respondents sought to foster a sense of loyalty to the company while learning to seek experience. There are also respondents who do not know.

When asked about the value, many respondents confuse interpret it so that researchers should equalize it with the norm to provoke understanding of respondents. Respondents interpret value as a binding walking rule, something that is considered important and the nature to be inculcated. One respondent said he did not know. All respondents stated that this company already has value, that is honesty in work, opening job field and prospering its employees. It's just that the implementation has not been supervised maximally and the openness of the boss to the opinion of the employees has not been applied. All respondents stated that the value of the company run is appropriate and nothing is against the value of each.

\section{Perception of Respondents in Establishing Corporate Culture Indicators}

Before entering the third part of the question, the researcher generates an understanding of vision, mission and values. It is intended that the researcher and the respondent are in the same view. All respondents stated that CV SAJADA requires a vision to bounce back. Respondents stated that the company needs to emphasize its vision to be a tough company. Being a company that can channel the products needed by the community, especially the Sibolga-Tapanuli Tengah area. Respondents also stated that the sense of kinship in this company is maintained. In addition, the need for selective attitudes in recruiting qualified human resources who share the same vision to build the company, have the awareness and willingness to work creatively in completing their work and uphold the values in their daily lives. If the company advanced, then automatically its employees can feel and improve the welfare of his life. So that employees work not only based on profit-oriented course.

Just like the vision, the company is also considered to have a mission. Starting from the improvement of the organizational structure of the company and also do the recruitment of human resources more selectively. Increased supervision is necessary so as not to form a loophole to commit fraud. The enforcement of the Company's Operational Standards (SOP) is considered important in order that the company's operations can run effectively and efficiently and not overlap. More emphasis on the discipline and responsibilities of employees in completing their work. Increase the profitability of the company by improving the performance of employees and also looking for opportunities other products needed by the market closely.

Furthermore, all respondents stated the importance of planting strong value in this company. Starting from the planting value of honesty, discipline, responsibility in completing the work, mutual respect the results and input of others, both between superiors and employees and with fellow employees. Respondents also added the importance of professionalism of work so that the strong family values created in this company are not damaged by the view that his work can be borne by his team mates. Strengthening in justice and religious values is also considered important so that everything done by its employees is based on worship and continues to feel watched by God Almighty.

\section{CONCLUSION}

From the exposure of the researcher's observation, the views of the owner and also the answers of all respondents, it can be concluded that CV SAJADA needs corporate transformation through the implementation of organizational culture indicators, namely vision, mission, and value. CV SAJADA must establish a noble vision, namely to be a company that capable of delivering quality products to the community by empowering human resources in the region.

CV SAJADA must also establish a clear mission. To become a reliable distribution company, there must be a firm Operational Standard (SOP) and also employ employees who share the same vision and uphold the religious values and values that apply to the community. Also, the company must also pay attention to the welfare of its employees, ranging from compensation to work-life balance.

Last but not least, CV SAJADA is in need of planting values. The first value to be maintained is a sense of kinship among employees as well as superiors. The second value is honesty. This value is an important demand based on the phenomena already described in this study. And the third value is employee professionalism that includes work discipline, mutual respect, team work and sense of responsibility.

\section{References}

[1] Tjiptono, Fandy, "Strategi Pemasaran”, Edisi 3, Yogyakarta ANDI, 2008

[2] Wibisono, "Manajemen Kinerja: Konsep Desain dan Teknik Meningkatkan Daya Saing Perusahaan”, Jakarta, Erlangga, 2006

[3] Dictionary Of Language and Culture, Longman

[4] Locke, Edwin A. \& Associates, "The Essence of Leadership: The Four Keys to Leading Successfully", MacMillan, Inc. New York. 1997

[5] Webster's Third New International Dictionary,Merriam Webster Inc., USA., 1993

[6] Endang Soemantri, "Pendidikan Moral”;Diktat, FPIPS IKIP Bandung, 1993, p.3.

[7] Ndraha, Taliziduhu,” Budaya Organisasi”, Jakarta, Rineka Cipta, 1997, p.7 
[8] Blumenthal, B. \& Hapeslagh, P., "Towards a Definition of Corporate Transformation”, Sloan Management Review, 35, 3, 1994, p. $101-106$.

[9] Robbins, S.P. "Perilaku Organisasi”, Jakarta, Prenhallindo, 1996
[10] Schein, E.H., “ Organizational Culture and Leadership”. Jossey-Bass, San Fransisco, 1996.

[11] Ndraha, Taliziduhu," Budaya Organisasi”, Jakarta, Rineka Cipta, 1997 